mgr Anna Starek

Uniwersytet Przyrodniczy w Lublinie

Biblioteka Główna

anna.starek@up.lublin.pl

mgr inż. Magdalena Piech

Uniwersytet Przyrodniczy w Lublinie

Biblioteka Główna

magdalena.piech@up.lublin.pl

\title{
BIBLIOTEKA - CENTRUM EDUKACYJNE CZY MIEJSCE SPOTKAŃ. HYBRYDA PRZESTRZENI W BIBLIOTEKACH AKADEMICKICH
}

\section{LIBRARY - EDUCATIONAL CENTER OR MEETING PLACE. SPACE HYBRIDS IN ACADEMIC LIBRARIES}

\begin{abstract}
Abstrakt
Celem artykułu jest próba ustalenia funkcji współczesnej zmodernizowanej biblioteki akademickiej, a zwłaszcza roli przestrzeni bibliotecznych. $\mathrm{Na}$ podstawie literatury przedmiotu oraz informacji zawartych na stronach domowych wybranych bibliotek (polskich i światowych) wskazano na przenikanie się przestrzeni edukacyjnej i towarzyskiej. Prezentowane oferty wskazują, że obecnie biblioteki akademickie pełnią zarówno rolę centrum edukacyjnego, jak i stanowią miejsce spotkań ich użytkowników.
\end{abstract}

Słowa kluczowe: biblioteka akademicka, społeczeństwo informacyjne, centrum edukacyjne, użytkownik, architektura biblioteki, przestrzeń biblioteczna.

\begin{abstract}
The article attempts to determine the function of a modernized academic library, especially the role of library spaces. The analysis of the information available in the literature and that gathered from selected library websites (Polish and foreign) shows that the educational and social spaces
\end{abstract}


intermingle. The presented cases indicate that academic libraries today function both as educational centers and meeting places of their users.

Keywords: academic library, information society, educational center, user, library architecture, library space.

\section{Wstęp}

Biblioteka jest organizacją podlegającą ewolucji, która musi stale dostosowywać się do nowoczesnego środowiska i współczesnych wyzwań. Oferta bibliotek powinna być dopasowana do oczekiwań użytkowników, które kształtują zarówno produkty, jak i usługi. Skutkuje to ciągłym badaniem oczekiwań oraz stosowaniem tzw. marketingu bibliotecznego ${ }^{1}$. Biblioteka naukowa stoi w obliczu procesu dostosowania swojej oferty do potrzeb jej użytkowników. Oprócz gromadzenia i udostępniania źródeł informacji, przystosowuje swoich użytkowników do umiejętnego przetwarzania wyszukanych danych i informacji. Dzisiejszy czytelnik jest członkiem społeczeństwa informacyjnego, a biblioteka akademicka - mobilnym centrum zarządzania wiedzą. Mobilność bibliotek akademickich to z jednej strony elektroniczne zasoby informacji udostępniane na różnych urządzeniach i w dowolnych miejscach, z drugiej zaś strony, to specyfika pracy współczesnego bibliotekarza. Biblioteka oraz jej pracownicy stają się dynamiczną społecznością, stale doskonalącą swoje umiejętności w celu zaspokojenia zmieniających się potrzeb swoich użytkowników ${ }^{2}$.

\section{Biblioteka akademicka w społeczeństwie informacyjnym i jej rola w strukturze uczelni}

Życie i działanie współczesnego człowieka wymaga od niego korzystania z różnorodnych informacji. Poza zasobami demograficznymi, surowcowymi i energetycznymi zasoby informacyjne, które obejmują osiągnięcia

1 K. Żmigrodzka: Biblioteka akademicka wsparciem gospodarki opartej na wiedzy. W: Biblioteka akademicka. Infrastruktura - uczelnia - otoczenie, Gliwice, 24-25 października 2013 r. Gliwice 2014, s. 398.

2 M. Jędrzejczak: Mobilna biblioteka akademicka jako centrum zarządzania wiedza. W: Biblioteka w komórce? Przyszłość usług bibliotecznych. Międzynarodowa Konferencja Biblioteki Uniwersytetu Łódzkiego. Łódź 2013, s. 245-252. 
nauki, kultury i sztuki, stanowią najistotniejszy składnik potencjału cywilizacyjnego nowego społeczeństwa informacyjnego ${ }^{3}$.

„Społeczeństwo informacyjne” to termin powszechnie używany zarówno w nauce, jak i w życiu codziennym. Po raz pierwszy pojawił się w artykule japońskiego etnologa Tadao Umesao w 1963 r. $^{4}$ Jego praca dotyczyła ewolucji teorii społeczeństwa opartego na technologiach informatycznych i przetwarzaniu informacji.

Biblioteki wychodzą naprzeciw wyzwaniom i potrzebom społeczeństwa informacyjnego, którego rozwój postulowała strategia lizbońska, kładąc nacisk na edukację mającą stanowić jedną z wiodących dziedzin w rozwoju społeczeństwa opartego na wiedzy.

Kierunki rozwoju bibliotek akademickich to przede wszystkim organizacja przestrzeni wiedzy, wspieranie biegłości w posługiwaniu się informacją oraz uświadamianie użytkownikom, że biblioteka jest najwłaściwszym miejscem do zdobywania wiarygodnej informacji, a bibliotekarze idealnymi przewodnikami po „oceanie informacji”" Biblioteki stały się miejscem pracy i nauki, ale też przyjazną przestrzenią, gdzie można się spotkać, porozmawiać, wymienić poglądy i odpocząć. Zadania, które niewątpliwie wpisują się w przestrzeń informacyjno-edukacyjną to:

- kształcenie (szkolenia w zakresie umiejętności informacyjnych);

- słuchanie (analizowanie i identyfikowanie potrzeb użytkowników poprzez badania ilościowe i jakościowe; istotne jest tutaj empatyczne wsłuchanie się w potrzeby użytkownika i spojrzenie na korzystanie z zasobów z jego perspektywy);

- informowanie (formy przekazu informacji naukowej; witryna biblioteki, wystawy tradycyjne i elektroniczne, współpraca bibliotek z międzynarodowymi firmami - zbieranie danych i ich udostępnianie, blogi, portale społecznościowe) $)^{6}$.

3 T. Goban-Klas, P. Sienkiewicz: Społeczeństwo informacyjne: szanse, zagrożenia, wyzwania. Kraków 1999, s. 42. Tryb dostępu: http://informacjacyfrowa.wsb.edu.pl/pdfs/ SpoleczenstwoInformacyjne.pdf [20 lipca 2018].

4 Za: J. Papińska-Kacperek: Nowa epoka - społeczeństwo informacyjne. W: Społeczeństwo informacyjne. Red. J. Papińska-Kacperek. Warszawa 2008, s. 14.

5 Ł. Maciejewska, B. Urbańczyk: Czego oczekuja użytkownicy biblioteki akademickiej $w$ dobie informacji elektronicznej. W: Biblioteka: klucz do sukcesu użytkowników. (ePublikacje instytutu INiB UJ. Red. Maria Kocójowa, Nr 5). Instytut Informacji Naukowej i Bibliotekoznawstwa, Uniwersytet Jagielloński. Kraków 2008, s. 48. Tryb dostępu: http://eprints.rclis.org/13039/1/maciejewskaurbanczyk-n.pdf [20 lipca 2018].

6 P. Studzińska-Jaksim: Kształcić, słuchać, informować. Rola i zadania nowoczesnych bibliotek akademickich. W: Biblioteka w komórce? Przyszłość usług bibliotecznych. Mię- 
Działalność dydaktyczno-edukacyjna bibliotek akademickich dotyczy kształcenia przede wszystkim użytkowników, ale również i samych bibliotekarzy. Wspomaganie procesu kształcenia przez biblioteki to przygotowanie użytkowników do sprawnego i samodzielnego poszukiwania informacji, jej selekcji, krytycznej oceny oraz wyboru tej najlepszej jakości mającej wartość naukową. Coraz częściej do prowadzenia takiej działalności, biblioteki wykorzystują Internet, korzystając $\mathrm{z}$ platform e-learningowych do kształcenia zdalnego.

Innym bardzo ważnym zadaniem biblioteki akademickiej jest działalność dokumentacyjna i bibliometryczna, ponieważ biblioteki naukowe są predysponowane do gromadzenia, opracowywania i przetwarzania danych dotyczących publikacji, raportów z badań, projektów. Prowadzą bibliografie publikacji pracowników, które stanowią nie tylko dokumentację działalności piśmienniczej pracowników uczelni, ale są również bazami wykorzystywanymi przez studentów poszukujących literatury do prac dyplomowych. Ponadto przyczyniają się do zwiększenia widoczności publikacji pracowników oraz są narzędziami umożliwiającymi raportowanie do Modułu Sprawozdawczego Polskiej Bibliografii Naukowej. Bazy umożliwiają generowanie raportów do parametryzacji, awansów zawodowych pracowników, są też przydatne przy ubieganiu się o granty, czy uczestnictwie w konkursach.

Uzupełnianie księgozbioru oraz zasobów elektronicznych o najbardziej aktualne źródła, to kolejna bardzo ważna misja biblioteki. Jest to szczególnie istotne dla nauk technicznych, przyrodniczych czy matematycznych, które należą do najszybciej rozwijających się dziedzin. Kształcenie na najwyższym poziomie wymusza posiadanie literatury najnowszej, stąd też bardzo ważna jest współpraca biblioteki z jednostkami uczelni oraz innymi użytkownikami w procesie gromadzenia literatury. Dlatego też wiele bibliotek polskich i zagranicznych oferuje możliwość zgłaszania przez użytkowników propozycji zakupu. W Bibliotece Głównej Uniwersytetu Przyrodniczego w Lublinie (BG) istnieje możliwość zgłoszenia zakupu zbiorów drukowanych poprzez zakładkę „Zaproponuj kupno książki” oraz zbiorów elektronicznych na platformie IBUK-Libra. Wiele bibliotek przygotowało w tym celu specjalne formularze do zgłoszenia propozycji tytułów książek, wśród nich jest Biblioteka Uniwersytecka w Bambergu?.

dzynarodowa Konferencja Biblioteki Uniwersytetu Łódzkiego. Łódź 2013, s. 134-145.

7 Bamberg University Library. Tryb dostępu: https://www.uni-bamberg.de/en/ub/ acquisition-suggestion/ [22 sierpnia 2018]. 


\section{Potrzeby i oczekiwania współczesnego użytkownika biblioteki naukowej}

Chcąc zaspokoić potrzeby współczesnego odbiorcy informacji biblioteki naukowej, należy je najpierw zidentyfikować. Może się to odbywać np. poprzez badanie ankietowe. Sposobem na komunikację z użytkownikiem, budowanie wizerunku, jak i realizowanie misji naukowo-kulturalnej jest wykorzystanie narzędzi Web 2.0, wśród których wymienić można media społecznościowe, jak np.: Facebook, Instagram oraz blog. Inne dominujące sposoby komunikacji $\mathrm{z}$ użytkownikiem $\mathrm{w}$ celu wypełnienia zadań naukowych, edukacyjnych czy informacyjnych, to wideo i transmisje na żywo, Wikipedia, serwis Youtube czy Twitter ${ }^{8}$. Bibliotekarze z Purdue University przeprowadzili badania mające na celu ustalenie, $\mathrm{z}$ jakich platform społecznościowych korzystają studenci, z jakich chcieliby, aby korzystały biblioteki i jakie treści chcieliby, aby biblioteki zamieszczały na każdej z platform. W tym celu przeprowadzili w 2017 r. ankietę, aby określić nawyki i preferencje studentów w mediach społecznościowych. Wyniki wykazały, że studenci używają obecnie Facebooka, Youtuba i Snapchata, a bibliotekę chcieliby zobaczyć na Facebooku, Instagramie i Twitterze9 .

Powyższe wyniki badań są sugestią dla bibliotek, aby opracować ulepszone kanały komunikacyjne oraz wyraźnie zaznaczać swoją obecność w mediach społecznościowych. W stosunku do narzędzi Web 2.0 pojawiały się jednakże głosy krytyki, gdyż interaktywność użytkownika, który może być jednocześnie i producentem, i odbiorcą tekstu, obrazu czy też dźwięku, jest dla niektórych krokiem wstecz, ponieważ dopuszczenie milionów internautów, niefachowców do tworzenia sieciowej rzeczywistości, pogłębia szum informacyjny, który jest główną „zmorą” Internetu ${ }^{10}$. Użytkownicy bibliotek akademickich to młodzi ludzie wychowani w poczuciu

8 K. Puksza, E. Witkowska: Facebook, Instagram, blog... i co dalej? - Biblioteka Uniwersytecka im. Jerzego Giedroycia w Białymstoku w mediach społecznościowych. „Biuletyn EBIB” 2018, nr 1(178). Tryb dostępu: http://open.ebib.pl/ojs/index.php/ebib/article/ view/614 [30 sierpnia 2018].

9 H. Howard, S. Huber, L. Carter, E. Moore: Academic Libraries on Social Media: Finding the Students and the Information They Want. "Information Technology \& Libraries” Vol. 37, nr 1 (2018), s. 11-15. Tryb dostępu: https://ejournals.bc.edu/ojs/index.php/ital/ article/view/10160/pdf [9 września 2018].

10 M. Wecko: Portal biblioteki pomostem $w$ procesie komunikacji $i$ wymiany informacji między biblioteka a jej użytkownikiem. W: Dolnośląskie Centrum Informacji Naukowej i Ekonomicznej - biblioteka otwarta. Pod red. B. Żmigrodzkiej. Wrocław 2011, s. 68. 
nieograniczonego dostępu do informacji. Ci „cyfrowi tubylcy” wykazują biegłość w obsłudze narzędzi informacyjnych, słabą ich stroną jest zaś przetwarzanie informacji, tj. wyszukiwanie, selekcja i ocena. Generacja Google nie jest zwiastunem końca bibliotek, lecz otwiera nowe możliwości na odegranie kluczowej roli w procesie kształtowania społeczeństwa opartego na wiedzy ${ }^{11}$. Na atrakcyjność biblioteki akademickiej w oczach współczesnego konsumenta informacji wpływa wizerunek biblioteki, wszelkie działania public relations, dostosowanie oferty do potrzeb współczesnego użytkownika, architektura budynku. Aby przyciągnąć pokolenie Google, biblioteki naukowe powinny dostosować swoją ofertę do aktualnego odbiorcy i zaplanować działania, które zwiększyłyby liczbę odwiedzających i korzystających użytkowników. Wydzielenie odrębnych miejsc do pracy indywidualnej czy też odpowiedniej przestrzeni do pracy grupowej i spotkań, jest dzisiaj oczywistością. Takie miejsca charakteryzują się wielką różnorodnością i występują praktycznie w każdej bibliotece akademickiej.

Witryna biblioteczna to doskonale miejsce promocji instytucji, narzędzie współpracy i komunikacji z użytkownikiem prezentujące działalność i zasoby biblioteki. Dzięki dobrej stronie internetowej oraz działaniom public relations zwiększył się zasięg oddziaływania biblioteki. Przykładem dobrej praktyki dopasowania strony internetowej do obowiązującej identyfikacji wizualnej jest Biblioteka Uniwersytecka w Santa Cruz ${ }^{12}$ czy też Biblioteka Uniwersytecka Uniwersytetu Humboldta w Berlinie ${ }^{13}$. Strony te bardzo dobrze korespondują z serwisami uczelnianymi, ponieważ wykazują spójność na poziomie wizualnym poprzez schematyczny układ czy też logo.

Dobra strona internetowa, która spełnia powyższe warunki, jest ponadto szczególnie ważna dla bibliotek cyfrowych, których odbiorcą jest użytkownik wirtualny. Wówczas sam budynek i wszelkie udogodnienia architektoniczne nie mają znaczenia, a witryna biblioteczna staje się wizytówką biblioteki. Biblioteki cyfrowe są odpowiedzią na rosnące wymagania użytkowników w zakresie nieograniczonej dostępności do zbiorów i jednym z przejawów aktywności współczesnej biblioteki akademickiej. Umożliwiają bezpłatne korzystanie o każdej porze i z dowolnego miejsca z wybranych zasobów bibliotecznych. Jest to szczególnie ważne w procesie kształcenia

11 S. Skórka: Biblioteka akademicka wobec wyzwań użytkowników „generacji Google”. „Biblioteka i Edukacja” 2012, nr 1, s. 1-3.

12 Biblioteka Uniwersytecka w Santa Cruz. Tryb dostępu: https://library.ucsc.edu/ [16 września 2018].

13 Biblioteka Uniwersytecka Uniwersytetu Humboldta w Berlinie. Tryb dostępu: https:// www.ub.hu-berlin.de/de/ [16 września 2018]. 
na odległość. Dzięki digitalizacji i tworzeniu bibliotek cyfrowych możliwe jest udostępnianie zasobów szerokiej liczbie użytkowników, ochrona i archiwizacja zbiorów czy też promowanie instytucji w skali globalnej. Digitalizacja przyczynia się do rozwiązania problemu niszczenia cennych zbiorów, w tym druków i rękopisów wymagających szczególnej ochrony, daje możliwość nie tylko utworzenia elektronicznych kopii archiwalnych, ale także ich upowszechniania. „Z ekonomicznego punktu widzenia zaletą cyfryzacji jest zmniejszenie zapotrzebowania na powierzchnie magazynowe"14. Biblioteki musiały szybko zareagować na nowe technologie, które dawały nowe narzędzia służące podtrzymywaniu kontaktu z czytelnikami.

W odpowiedzi na Web 2.0 pojawił się termin „Library 2.0” (Biblioteka 2.0). Biblioteka 2.0, to biblioteka społeczności czytelników i bibliotekarzy cyfrowych. Sam termin oznacza wyszukiwanie informacji przez bibliotekarza przy jednoczesnym zaangażowaniu użytkownika, którego aktywność jest nieodłącznym elementem Biblioteki 2.0. Jej ideą jest koncentracja na użytkowniku, który chce uczestniczyć w działalności biblioteki, zaznaczając swoją obecność przez komunikatory, kanały RSS, wiki, blogi czy tagi. Dzięki możliwości wykorzystania tych narzędzi ma miejsce dwukierunkowy przepływ informacji między bibliotekarzem a użytkownikiem, co przyczynia się do udoskonalania usług bibliotecznych. Dziś często pierwszy kontakt z biblioteką odbywa się nierzadko za pomocą stron WWW biblioteki, które są portalem lub serwisem bibliotecznym. Portale te, wzbogacone o nowe technologie, umożliwiają dialog między biblioteką a jej użytkownikami. W elektronicznej komunikacji z użytkownikiem jest wiele różnorodnych form, m.in.: poczta elektroniczna, formularze (WWW, interaktywne), newslettery, e-ankiety, księgi gości, listy i fora dyskusyjne, czat. Ciekawym rozwiązaniem jest specjalistyczne oprogramowanie typu Web Contact Center, którego przykładem jest Co-browsing, pozwalające oglądać ekran użytkownika, a użytkownikowi ekran bibliotekarza ${ }^{15}$.

Nowoczesne technologie, kanały komunikacji z użytkownikiem, odpowiednia witryna biblioteczna, to istotne elementy, mające decydujący wpływ na liczbę wirtualnych użytkowników biblioteki. Aby jednak wzrosła liczba użytkowników biblioteki fizycznie ją odwiedzających, musi być ona atrakcyjna pod względem architektonicznym i mieć tak zorganizowaną

14 E. Dobrzyńska-Lankosz: Biblioteka cyfrowa jako jeden z przejawów aktywności współczesnej biblioteki akademickiej. W: Biblioteka $w$ kryzysie czy kryzys $w$ bibliotece?: IV Konferencja Biblioteki Politechniki Łódzkiej. Łódź 2010, s. 65.

15 M. Wecko: Portal biblioteki..., dz. cyt., s. 69-73. 
przestrzeń, aby zachęcić użytkowników do odwiedzin nie tylko w celach naukowych, ale także korzystania z jej działań kulturotwórczych. Biblioteka stała się miejscem do pracy grupowej i indywidualnej, stąd też powszechnym stało się wyodrębnienie przestrzeni na pokoje do pracy grupowej i indywidualnej, jak i również stanowisk posiadających wejścia do prywatnych laptopów. Równie ważnym stała się organizacja miejsca na pracownie kserograficzne, skanery, miejsca do digitalizacji zbiorów, strefy chillout’u czy też kąciki gastronomiczne. Tak więc w nowoczesnej bibliotece akademickiej przewidziane powinny być miejsca do nauki i udzielania informacji oraz spędzania czasu wolnego.

Przy projektowaniu budynków bibliotek istotne znaczenie ma ich funkcjonalność. H. Faulkner-Brown podkreśla zasadę flexibility, elastyczności budynku, tak aby było możliwe przeorganizowanie danej struktury, przystosowanie jej do zmieniających się potrzeb i wymagań użytkowników ${ }^{16}$.

\section{Oferta biblioteki akademickiej jako centrum edukacyjnego}

We współczesnych bibliotekach akademickich edukacja informacyjna stanowi stały element programu studiów. Biblioteki naukowe opracowały własne strategie szkoleń i siatki przedmiotów. Są to już nie tylko kursy z przysposobienia bibliotecznego dla studentów pierwszego roku studiów, ale również zajęcia $\mathrm{z}$ metodyki wyszukiwania źródeł informacji naukowej ${ }^{17}$ kierowane do pracowników naukowych i doktorantów. Przykładem jest inicjatywa Biblioteki Politechniki Lubelskiej oferująca szkolenia dotyczące informacji naukowej, zasobów naukowych, zarządzania bibliografią, czy E-resources available through your library kierowane do studentów i doktorantów obcojęzycznych ${ }^{18}$.

Bardzo bogaty pakiet szkoleń oferuje Biblioteka Uniwersytecka w Wiedniu. Szkolenia tam prowadzone dotyczą technik wyszukiwawczych i innych

16 H. Faulkner-Brown: Some thoughts on the design of major library buildings. W: Intelligent Library Buildings proceedings of the Tenth Seminar of the IFLA Section on Library Buildings and Equipment: The Hague, Netherlands, 24-29 August 1997. Ed. by M.-F. Bisbrouck and M. Chauveinc; International Federation of Library Associations and Institutions. München 1999, s. 9-24.

17 Biblioteka Główna Uniwersytetu Przyrodniczego w Lublinie. Tryb dostępu: http:// bg.up.lublin.pl/4715/?rid=10744 [16 września 2018].

18 S. Pietrzyk-Leonowicz: Miejsce biblioteki w strukturze uczelni. W: Z problemów bibliotek naukowych Wrocławia 13, V Wrocławskie Spotkania Bibliotekarzy. Red. A. Łuszpak, J. Leśniewski. Wrocław 2017, s. 26. 
ważnych tematów bibliotecznych, i mają wspierać kompetencje informacyjne użytkowników biblioteki. Zajęcia są podzielone na dwa główne bloki: szkolenia ogólne i szkolenia online. Szkolenia ogólne obejmują m.in.: podstawy korzystania z Biblioteki, wykorzystanie zasobów elektronicznych, wyszukiwanie „pod opieką”, zajęcia korzystania z wypożyczalni międzybibliotecznej, prawo autorskie i plagiaryzm. Szczególnie interesującą ofertę szkoleniową przygotowano dla doktorantów: warsztaty składające się z kilku bloków tematycznych i zawierające m.in.: wyszukiwanie literatury i zarządzanie przez menedżery bibliografii, zastosowanie wskaźników altmetrycznych, strategie publikowania w modelu open access, prezentację wyników badań, pisanie, prezentacje i komunikację w języku angielskim, wspieranie badań i składanie wniosków o dofinansowanie, planowanie kariery i zarządzanie projektami, weryfikację danych ${ }^{19}$. W odróżnieniu od innych ofert szkoleń bibliotek akademickich grupą docelową w Bibliotece Uniwersyteckiej w Wiedniu mogą być nie tylko studenci, doktoranci i pracownicy naukowi, ale dowolna grupa użytkowników tzw. interested public ${ }^{20}$.

W większości szkół wyższych szkolenie biblioteczne ma charakter obowiązkowy, w niektórych z wpisem do indeksu. Głównymi uczestnikami szkoleń są studenci I stopnia studiów stacjonarnych i niestacjonarnych, którym przekazuje się informacje na temat podstawowych usług i narzędzi bibliotecznych. Zdecydowanie rzadziej szkolenia skierowane są do studentów II i III stopnia, co oznacza, że ta forma edukacji bibliotecznej sprowadza się do tzw. przysposobień bibliotecznych. Większość bibliotek szkoli także w zakresie wyszukiwania w licencjonowanych bazach danych ${ }^{21}$.

Przy projektowaniu oferty edukacyjnej istotne jest rozpoznanie opinii, nawyków, posiadanych umiejętności i potrzeb informacyjnych odbiorców szkoleń, np. w formie badania ankietowego. Tego typu badanie odbyło się w Bibliotece Uniwersyteckiej w Warszawie i dostarczyło wielu ciekawych obserwacji i wniosków istotnych dla całego środowiska akademickiego. Zwrócono uwagę, że szkolenia biblioteczne powinny obejmować mniejszy zakres materiału i być silniej ukierunkowane tematycznie.

19 Biblioteka Uniwersytecka w Wiedniu. Tryb dostępu: https://bibliothek.univie.ac.at/ schulungen.html [21 sierpnia 2018].

20 Tamże. Tryb dostępu: https://bibliothek.univie.ac.at/schulungen-eressourcen_grundlagen.html [21 sierpnia 2018].

21 J. Dziak, E. Rozkosz, M. Karciarz, Z. Wiorogórska: Edukacja informacyjna w polskich bibliotekach akademickich - raport z badań. „Bibliotheca Nostra, Śląski Kwartalnik Naukowy" 2013, nr 1(31), s. 26-41. Tryb dostępu: http://hdl.handle.net/11479/30 [13 października 2018]. 
Szkolenia jednorazowe cechują się niską efektywnością. Spośród trzech form szkoleniowych: online, $\mathrm{w}$ bibliotece $\mathrm{z}$ biernym uczestnictwem i w bibliotece $\mathrm{z}$ uczestnictwem aktywnym, zdecydowana większość respondentów wybrała aktywną formę szkolenia w bibliotece. Tematy, które wzbudzają największe zainteresowanie odbiorców, to przede wszystkim tworzenie bibliografii i wyszukiwanie informacji połączone z jej ewaluacją. Ogromne znaczenie ma też wsparcie instytucjonalne umożliwiające rozwijanie kompetencji dydaktycznych bibliotekarzy poprzez uczestnictwo w kursach, szkoleniach z zakresu pedagogiki, metod nauczania czy tworzenia szkoleń online ${ }^{22}$.

Biblioteka Uniwersytetu Technicznego w Tallinie organizuje szkolenia dla nowych użytkowników. Odbywają się one w formie e-szkoleń na platformie Moodle lub za pomocą filmów instruktażowych na stronie biblioteki, także w języku angielskim. Po zakończonym kursie każdy może sprawdzić swoją wiedzę, rozwiązując quiz. Biblioteka oferuje też szkolenia specjalistyczne z zakresu e-źródeł, czy organizowania warsztatu pracy naukowo-dydaktycznej ${ }^{23}$.

\section{Biblioteka akademicka jako miejsce spotkań}

Biblioteki akademickie, oprócz funkcji informacyjnej i edukacyjnej pełnią coraz częściej funkcję społeczną i kulturalną. Z powodzeniem wchodzą w rolę tzw. trzeciego miejsca, w którym łączy się praca naukowo-badawcza z aktywnością towarzyską. Rośnie znaczenie bibliotek jako miejsc popularnych w środowisku akademickim i lokalnym ${ }^{24}$. Działalność kulturotwórcza bibliotek naukowych najczęściej realizuje się poprzez wykłady, szkolenia, promocje książek, prezentacje kolekcji zbiorów, spotkania z autorami, twórcami nauki i sztuki, konkursy i formy wizualne. Wydarzenia te są zazwyczaj poprzedzone odpowiednią promocją, aby mogły

22 L. Nalewajska: Proces tworzenia oferty edukacyjnej $w$ bibliotece akademickiej - na przykładzie Biblioteki Uniwersyteckiej w Warszawie. „Przegląd Biblioteczny” 2018, z. 2, s. 165-193.

23 D. Woźniak: Biblioteka Uniwersytetu Technicznego $w$ Tallinnie - wrażenia z pobytu w ramach programu Erasmus+. „Biuletyn EBIB” 2017, nr 4(174). Tryb dostępu: http:// open.ebib.pl/ojs/index.php/ebib/article/view/540 [3 października 2018].

24 K. Olesiak : Działalność edukacyjno-kulturalna bibliotek akademickich na przykładzie Biblioteki Głównej Uniwersytetu Pedagogicznego. „Biuletyn EBIB” 2016, nr 5(167). Tryb dostępu: http://open.ebib.pl/ojs/index.php/ebib/article/view/460 [3 października 2018]. 
zaistnieć w świadomości odbiorców. Przedsięwzięcia naukowo-kulturalne, edukacyjne i artystyczne budują pozytywny obraz biblioteki i przyciągają czytelników, zachęcając ich do regularnych odwiedzin i korzystania ze stałej oferty placówki.

Do ważnych corocznych wydarzeń akcentowanych w wielu bibliotekach, również akademickich, należy Tydzień Bibliotek organizowany w maju, którego celem jest promocja czytelnictwa i działalności bibliotek. Wydarzeniu towarzyszą różne inicjatywy, kierowane praktycznie do wszystkich grup wiekowych. W Bibliotece Głównej Uniwersytetu Przyrodniczego w Lublinie odbyły się warsztaty, wystawy, konkursy i wykłady. Zorganizowane zostały wystawy: reprintów oraz książek o intrygujących tytułach. Natomiast na tarasie Biblioteki urządzono strefę relaksu, gdzie można było skorzystać z gier planszowych, złożyć origami, pokolorować antystresową zakładkę do książki. W całym budynku na spostrzegawczych czekały ciekawostki na temat nośników i technik czytania, a dla kreatywnych został zorganizowany konkurs na hasło promujące czytelnictwo ${ }^{25}$. W ramach Dnia Otwartego Funduszy Europejskich zaprezentowano najważniejsze informacje i ciekawostki o stolicach europejskich, przeprowadzono wykłady o kajakarstwie morskim oraz o kuchni śródziemnomorskiej. Ostatni wykład wzbudził duży entuzjazm wśród uczestników, którymi byli uczniowie technikum gastronomiczno-hotelarskiego w Lublinie, ponieważ połączony był z degustacją pizzy ${ }^{26}$. Takie spotkania czynią bibliotekę bliższą i tworzą jej pozytywny wizerunek.

Biblioteki celebrują ponadto święta międzynarodowe, jak np.: Światowy Dzień Bibliotekarzy i Bibliotek, Światowy Dzień Książki i Praw Autorskich, Międzynarodowy Dzień Lasów. Wydarzenia te organizowane są samodzielnie przez jednostki lub we współpracy ze studenckimi kołami naukowymi. Pozytywny wizerunek jednostki budowany jest przez organizowanie akcji charytatywnych. Biblioteka Główna Uniwersytetu Przyrodniczego w Lublinie wzięła udział w akcji „Antykwariat marzeń”, polegającej na zbiórce książek, a następnie przekazaniu ich na kiermasz, z którego dochód został przeznaczony na spełnianie marzeń ciężko chorych dzieci² ${ }^{27}$.

25 Biblioteka Główna Uniwersytetu Przyrodniczego w Lublinie. Tryb dostępu: http:// bg.up.lublin.pl/biblioteka/?page=4\&rid=14887 [18 września 2018].

26 Tamże. Tryb dostępu: http://bg.up.lublin.pl/biblioteka/?page=4\&rid=14884 [18 września 2018].

27 Tamże. Tryb dostępu: https://www.facebook.com/bguplublin [3 października 2018]. 
W wielu miastach Polski organizowane są festiwale nauki, w które aktywnie włączają się biblioteki. Są to wydarzenia o charakterze naukowo-kulturalnym i jednocześnie promującym i popularyzującym najnowsze osiągnięcia naukowe i techniczne. W Lublinie deklaracja o powołaniu Lubelskiego Festiwalu Nauki (LFN) została podpisana przez rektorów pięciu lubelskich uczelni i dyrektora Instytutu Agrofizyki Polskiej Akademii Nauk. Dała początek największej imprezie popularnonaukowej na Lubelszczyźnie, która trwale wpisała się w przestrzeń społeczną i kulturową Lublina i regionu. Działalność bibliotek akademickich Lublina w czasie LFN widoczna jest w organizacji wykładów popularnonaukowych wygłaszanych przez bibliotekarzy („Herbata esencją mądrości”, „Miód mądrością medycyny naturalnej”, „Niezwykłe losy wynalazków i ich twórców”) i zaproszonych gości („Kajakowe opowieści” czy „Natura jest dziedziną wolności”). Projekty kierowane są również do uczniów młodszych klas szkoły podstawowej. W czasie ostatniej edycji festiwalu realizowane były projekty: „Poszukiwanie skarbu w bibliotece” oraz warsztaty plastyczne polegające na zdobieniu płóciennych toreb za pomocą szablonów.

Podczas organizowanych pikników naukowych proponowane są prezentacje $\mathrm{z}$ wykorzystaniem najnowszych osiągnięć i udogodnień dla osób z dysfunkcją wzroku i słuchu. Dużym zainteresowaniem cieszą się warsztaty z kaligrafii (pisanie gęsim piórem), czy pisania na maszynie, które młodym osobom ukazują historię piśmiennictwa. Bibliotekarze odważnie prezentują tematy niezwiązane z czytelnictwem, organizując m.in. warsztaty ilustracji żurnalowej/modowej poprowadzone przez zaproszonego gościa.

W bibliotekach akademickich odbywają się także cykliczne spotkania kierowane przede wszystkim do środowiska akademickiego, ale także do wszystkich zainteresowanych. Jako przykład można podać comiesięczne wykłady otwarte, dotyczące różnorodnej tematyki, np. z cyklu „Sekrety Natury”, które przyczyniają się do budowania i wzmocnienia kontaktów międzyludzkich i wymiany doświadczeńn ${ }^{28}$. Szczególnie ważne jest to w dzisiejszych czasach, w których technologia dominuje w życiu człowieka.

28 E. Kosik: Kreowanie wizerunku bibliotek poprzez imprezy społeczno-kulturalne. „Biuletyn EBIB” 2016, nr 2(164). Tryb dostępu: http://open.ebib.pl/ojs/index.php/ebib/article/view/418 [3 października 2018]. 


\section{Podsumowanie}

Biblioteki akademickie stoją przed kolejnym wyzwaniem związanym z wejściem w życie Ustawy z dnia 20 lipca 2018 r. - Prawo o szkolnictwie wyższym $i$ nauce, $\mathrm{w}$ związku $\mathrm{z}$ tym muszą sprostać stojącym przed nimi wymaganiom. W myśl ustawy w uczelni ma działać system biblioteczno-informacyjny, którego podstawę stanowi biblioteka (art. 54.1), zaś jednym z zadań uczelni jest „Upowszechnianie i pomnażanie osiągnięć nauki, kultury narodowej i techniki, w tym poprzez gromadzenie i udostępnianie zbiorów bibliotecznych i informacyjnych" (art. 11).

Centrum Kształcenia IDEA oferuje bogaty wachlarz szkoleń kierowany do jednostek naukowych. Dotyczą one, m.in. Ustawy 2.0 i interpretacji zawartych w niej postulatów, warsztatu pracy naukowca - wykorzystania narzędzi wspomagających proces pisania tekstów (w tym menedżerów bibliografii), wyszukiwania źródeł, udostępniania publikacji w Internecie, pisania artkułów naukowych, promocji i budowania wizerunku uczelni ${ }^{29}$. Szkolenia są dość kosztowne i nie każda jednostka naukowa może sobie pozwolić na wysłanie swojego przedstawiciela. Pojawia się zatem pytanie, czy biblioteka naukowa nie mogłaby wyjść z ofertą tego typu szkoleń do swojej uczelni? Wymagałoby to od niej oczywiście odpowiedniego przygotowania formalnego, opracowania programów, w tym rzetelnego przygotowania bibliotekarzy. Inną tematyką szkolenia, której biblioteka mogłaby się podjąć, to np. zagadnienie wskaźników altmetrycznych czy nowych narzędzi bibliometrycznych: InCites na platformie Web of Sciences oraz SciVal na platformie Scopus. Zarówno na jedno, jak i na drugie narzędzie została zamówiona przez Ministerstwo Nauki i Szkolnictwa Wyższego licencja pilotażowa na 2018 r. Szczególnie ważna jest wiedza na temat funkcjonalności i zastosowania narzędzia analitycznego SciVal, które będzie źródłem do pobrania wskaźników i zagregowanych danych bibliometrycznych na potrzeby przygotowania rankingu Perspektyw oraz oceny jednostki.

Ze względu na dynamiczny rozwój otwartej nauki, która zakłada, że wiedza naukowa powinna być publicznie udostępniana, w gestii bibliotek naukowych leży promowanie otwartości poprzez różne działania, jak, np. popularyzowanie open data day ${ }^{30}$, czy też umieszczenie na swojej

29 Centrum Kształcenia Idea. Tryb dostępu: http://cknik.pl/ [23 sierpnia 2018].

30 Biblioteka Politechniki Wrocławskiej. Tryb dostępu: http://biblioteka.pwr.edu.pl/aktualnosci/open-data-day-2018-111.html [24 sierpnia 2018]. 
stronie domowej odrębnej zakładki z informacją o open access ${ }^{31}$. Publikowanie w otwartym dostępie i regularne udostępnianie danych badawczych w portalach społecznościowych (np. ResearchGate, Academia.edu), czy też w otwartych czasopismach i repozytoriach, przynosi korzyści zarówno użytkownikom, jak i autorom (rozwój kariery zawodowej, wzbogacenie profilu zawodowego, budowanie sieci kontaktów). Ponadto prace zamieszczone w otwartym dostępie mają większą liczbę cytowań. Korzyści dla autorów przekładają się na korzyści dla uczelni.

Otwartość biblioteki naukowej wyraża się poprzez otwarty dostęp do zbiorów, przyjazną przestrzeń dla użytkownika, która jest dla niego nie tylko miejscem zdobywania wiedzy, pracy i nauki, ale również odpoczynku i relaksu. Biblioteka spełnia zatem rolę zarówno centrum edukacyjnego, jak i miejsca spotkań.

\section{Bibliografia}

1. Bamberg University Library. Tryb dostępu: https://www.uni-bamberg.de/en/ ub/acquisition-suggestion/ [22 sierpnia 2018].

2. Biblioteka Główna Politechniki Warszawskiej. Tryb dostępu: http://www. bg.pw.edu.pl/index.php/ruch-open-access [24 sierpnia 2018].

3. Biblioteka Główna Uniwersytetu Przyrodniczego w Lublinie. Facebook. Tryb dostępu: https://www.facebook.com/bguplublin [3 października 2018].

4. Biblioteka Główna Uniwersytetu Przyrodniczego w Lublinie. Tryb dostępu: http://bg.up.lublin.pl/4715/?rid=10744 [16 września 2018]; http://bg.up.lublin. pl/biblioteka/?page=4\&rid=14887 [18 września 2018]; http://bg.up.lublin.pl/ biblioteka/?page $=4 \&$ rid $=14884$ [18 września 2018].

5. Biblioteka Politechniki Wrocławskiej. Tryb dostępu: http://biblioteka.pwr.edu. pl/aktualnosci/open-data-day-2018-111.html [24 sierpnia 2018].

6. Biblioteka Uniwersytecka Uniwersytetu Humboldta w Berlinie. Tryb dostępu: https://www.ub.hu-berlin.de/de/ [16 września 2018].

7. Biblioteka Uniwersytecka w Santa Cruz. Tryb dostępu: https://library.ucsc.edu/ [16 września 2018].

8. Biblioteka Uniwersytecka w Wiedniu. Szkolenie. Tryb dostępu: https://bibliothek.univie.ac.at/schulungen.html [21 sierpnia 2018].

9. Biblioteka Uniwersytecka w Wiedniu. Wykorzystanie e-zasobów: podstawy. Tryb dostępu: https://bibliothek.univie.ac.at/schulungen-eressourcen_grundlagen.html [21 sierpnia 2018].

10. Centrum Kształcenia Idea. Tryb dostępu: http://cknik.pl/ [23 sierpnia 2018].

31 Biblioteka Główna Politechniki Warszawskiej. Tryb dostępu: http://www.bg.pw.edu.pl/ index.php/ruch-open-access [24 sierpnia 2018]. 
11. Dobrzyńska-Lankosz E.: Biblioteka cyfrowa jako jeden z przejawów aktywności współczesnej biblioteki akademickiej. W: Biblioteka w kryzysie czy kryzys w bibliotece?: IV Konferencja Biblioteki Politechniki Łódzkiej. Łódź 2010, s. 65.

12. Dziak J., Rozkosz E., Karciarz M., Wiorogórska Z.: Edukacja informacyjna $w$ polskich bibliotekach akademickich - raport z badań. „Bibliotheca Nostra, Śląski Kwartalnik Naukowy" 2013, nr 1(31), s. 26-41. Tryb dostępu: http://hdl. handle.net/11479/30 [13 października 2018].

13. Faulkner-Brown H.: Some thoughts on the design of major library buildings. W: Intelligent Library Buildings proceedings of the Tenth Seminar of the IFLA Section on Library Buildings and Equipment: The Hague, Netherlands, 24-29 August 1997. Ed. by M.-F. Bisbrouck and M. Chauveinc; International Federation of Library Associations and Institutions. München 1999, s. 9-24.

14. Goban-Klas T., Sienkiewicz P.: Społeczeństwo informacyjne: szanse, zagrożenia, wyzwania. Kraków 1999.

15. Howard. H., Huber S., Carter L., Moore E.: Academic Libraries on Social Media: Finding the Students and the Information They Want. „Information Technology \& Libraries" Vol. 37, nr 1 (2018), s. 11-15. Tryb dostępu: https://ejournals.bc.edu/ojs/index.php/ital/article/view/10160/pdf [9 września 2018].

16. Jędrzejczak M.: Mobilna biblioteka akademicka jako centrum zarządzania wiedza. W: Biblioteka w komórce? Przyszłość usług bibliotecznych. Międzynarodowa Konferencja Biblioteki Uniwersytetu Łódzkiego. Łódź 2013, s. 245-252.

17. Kosik E.: Kreowanie wizerunku bibliotek poprzez imprezy społeczno-kulturalne. „Biuletyn EBIB” 2016, nr 2(164). Tryb dostępu: http://open.ebib.pl/ojs/index.php/ebib/article/view/418 [3 października 2018].

18. Maciejewska Ł., Urbańczyk B.: Czego oczekuja użytkownicy biblioteki akademickiej $w$ dobie informacji elektronicznej. W: Biblioteka: klucz do sukcesu użytkowników (ePublikacje instytutu INiB UJ. Red. Maria Kocójowa, Nr 5). Instytut Informacji Naukowej i Bibliotekoznawstwa, Uniwersytet Jagielloński. Kraków 2008, s. 42-52. Tryb dostępu: http://eprints.rclis.org/13039/1/maciejewskaurbanczyk-n.pdf [20 lipca 2018].

19. Nalewajska L.: Proces tworzenia oferty edukacyjnej w bibliotece akademickiejna przykładzie Biblioteki Uniwersyteckiej w Warszawie. „Przegląd Biblioteczny" 2018, z. 2, s. 165-193.

20. Olesiak K.: Działalność edukacyjno-kulturalna bibliotek akademickich na przykładzie Biblioteki Głównej Uniwersytetu Pedagogicznego. „Biuletyn EBIB” 2016, nr 5(167). Tryb dostępu: http://open.ebib.pl/ojs/index.php/ebib/article/ view/460 [3 października 2018].

21. Pietrzyk-Leonowicz S.: Miejsce biblioteki w strukturze uczelni. W: Z problemów bibliotek naukowych Wrocławia 13, V Wrocławskie Spotkania Biblioteka$r z y$. Red. A. Łuszpak, J. Leśniewski. Wrocław 2017, s. 19-34.

22. Puksza K., Witkowska E.: Facebook, Instagram, blog... i co dalej? - Biblioteka Uniwersytecka im. Jerzego Giedroycia w Białymstoku w mediach społecznościowych. „Biuletyn EBIB” 2018, nr 1(178). Tryb dostępu: http://open.ebib.pl/ ojs/index.php/ebib/article/view/614 [30 sierpnia 2018].

23. Skórka S.: Biblioteka akademicka wobec wyzwań użytkowników „generacji Google”. „Biblioteka i Edukacja” 2012, nr 1, s. 1-3. 
24. Społeczeństwo informacyjne. Red. J. Papińska-Kacperek. Warszawa 2008.

25. Studzińska-Jaksim P.: Kształcić, słuchać, informować. Rola i zadania nowoczesnych bibliotek akademickich. W: Biblioteka w komórce? Przyszłość usług bibliotecznych. Międzynarodowa Konferencja Biblioteki Uniwersytetu Łódzkiego. Łódź 2013, s. 134-145.

26. Wecko M.: Portal biblioteki pomostem w procesie komunikacji i wymiany informacji między bibliotekq a jej użytkownikiem. W: Dolnośląskie Centrum Informacji Naukowej i Ekonomicznej - biblioteka otwarta. Pod red. B. Żmigrodzkiej. Wrocław 2011, s. 68-73.

27. Woźniak D.: Biblioteka Uniwersytetu Technicznego w Tallinnie - wrażenia $z$ pobytu $w$ ramach programu Erasmus+. „Biuletyn EBIB” 2017, nr 4(174). Tryb dostępu: http://open.ebib.pl/ojs/index.php/ebib/article/view/540 [3 października 2018].

28. Żmigrodzka K.: Biblioteka akademicka wsparciem gospodarki opartej na wiedzy. W: Biblioteka akademicka. Infrastruktura - uczelnia - otoczenie, Gliwice, 24-25 października 2013 r. Gliwice 2014, s. 393-409. 